\title{
Funkcje gospodarcze regionu miejskiego Nowosybirska. Geneza i współczesne trendy rozwojowe
}

\author{
Economic functions of urban region of Novosibirsk. \\ The genesis and contemporary development trends
}

\author{
MARCIN WÓJCIK, PAULINA TOBIASZ-LIS \\ Katedra Geografii Regionalnej i Społecznej, Uniwersytet Łódzki \\ 90-142 Łódź, ul. Kopcińskiego 31 \\ marcin.wojcik@geo.uni.lodz.pl,paulina.tobiasz@geo.uni.lodz.pl
}

Zarys treści. Celem artykułu jest identyfikacja funkcji dominujących i wyjaśnienie ich przestrzennego zróżnicowania w regionie Nowosybirska, na przykładzie wybranych rejonów i miast położonych wzdłuż linii kolejowej Nowosybirsk-Czerepanowo (końcowa stacja regionalnych połączeń kolejowych) na dystansie około $100 \mathrm{~km}$. Pasmo to wybrano nie tylko ze względu na ciągłość zagospodarowania osadniczego, ale również z uwagi na występowanie różnych typów funkcjonalnych miast, od ściśle powiązanego z rdzeniem Berdska, przez silnie uprzemysłowiony w okresie sowieckim Iskitim, po peryferyjny ośrodek lokalny - Czerepanowo. Przyjęcie układu od rdzenia do strefy o słabnących bezpośrednich związkach z Nowosybirskiem pozwoliło określić kierunkowy profil regionu miejskiego w zakresie głównych funkcji w poszczególnych ośrodkach.

Słowa kluczowe: region miejski, centrum i peryferie, struktura funkcjonalna, przemiany demograficzne, metoda profilu kierunkowego, baza ekonomiczna.

\section{Wprowadzenie}

Powstanie regionu miejskiego jest wyrazem tworzenia się specjalizacji funkcjonalnej w skali regionalnej (Korcelli, 1981; Rykiel, 2002). Koncepcja „regionu miejskiego" odnosi się do obserwacji dobowych ruchów ludności, a za ich miarę można przyjąć powiązania w regionalnym systemie transportu zbiorowego. Niniejsze opracowanie koncentruje się na zależnościach funkcjonalnych w regionie miejskim Nowosybirska, stanowiącym pewien podsystem osadniczy, w którym istnieją ścisłe, bezpośrednie związki pomiędzy miastem - rdzeniem tego regionu oraz jego strefą peryferyjną. 
Do analizy cech ekonomicznych oraz zmian liczby ludności ${ }^{1}$, przyjęto cały rdzeń regionu miejskiego, czyli miasto Nowosybirsk oraz jego bezpośrednie otoczenie (Region Nowosybirski). ${ }^{2} \mathrm{~W}$ strefie peryferyjnej regionu miejskiego opracowano natomiast studium przypadku, do którego wybrano jednostki terytorialne (administracyjne) tworzące południowe pasmo osadnicze, ukształtowane wzdłuż linii kolejowej Nowosybirsk-Czerepanowo (końcowa stacja regionalnych połączeń kolejowych) na dystansie około $100 \mathrm{~km}$ (ryc. 1). Pasmo to wybrano nie tylko ze względu na ciągłość zagospodarowania, ale również z uwagi na istnienie tu miast reprezentujących różne typy funkcjonalne, od ściśle powiązanego z rdzeniem Berdska, przez silnie uprzemysłowiony w okresie sowieckim Iskitim, po peryferyjny ośrodek lokalny - Czerepanowo. Przyjęcie układu od rdzenia do stre-

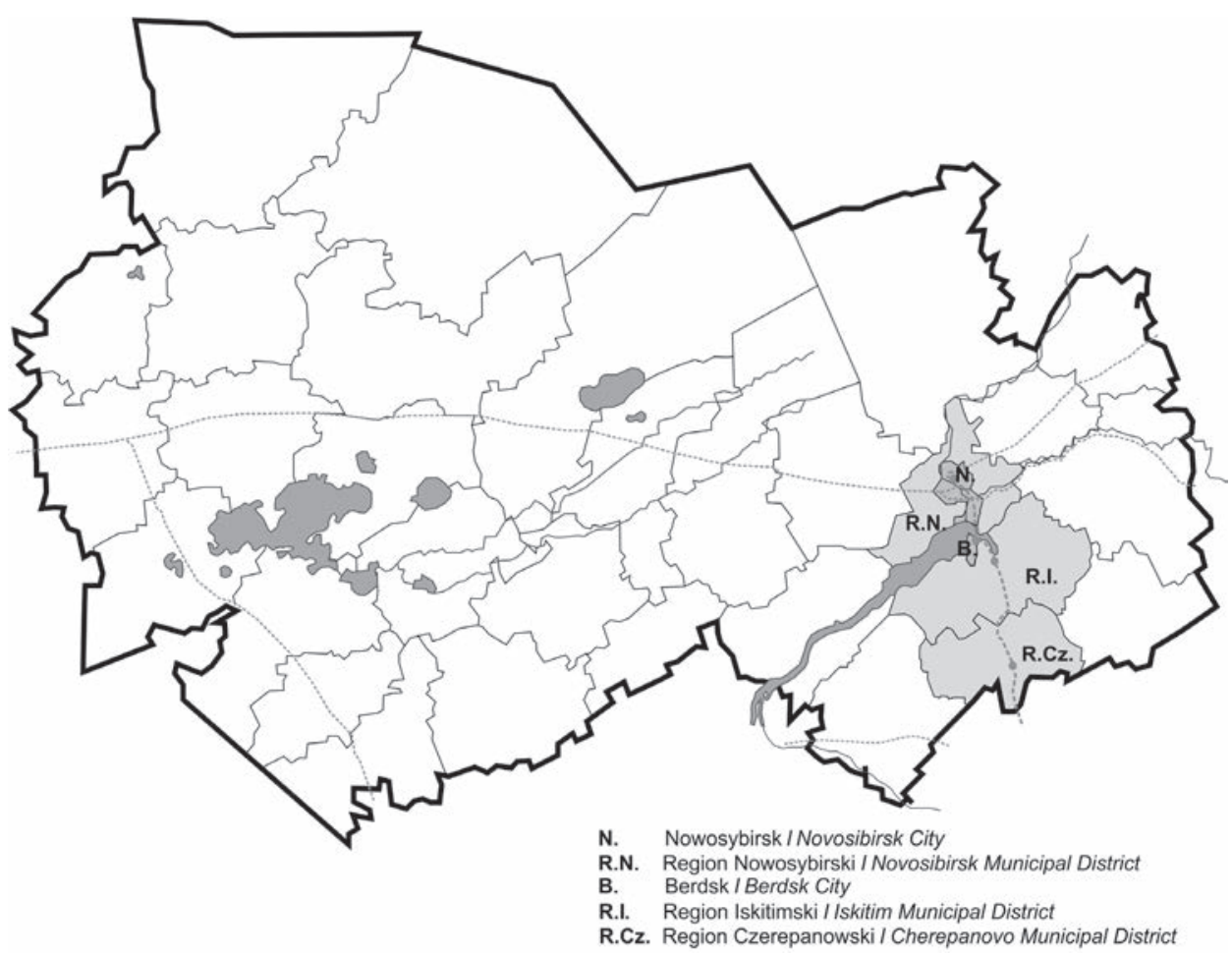

Ryc. 1. Jednostki terytorialne wybrane do badań na tle podziału administracyjnego

Obwodu Nowosybirskiego

Wszystkie ryciny są opracowaniem autorskim.

Territorial units selected for study within the administrative division

of the Novosibirskiy Region

All figures are the work of the authors.

\footnotetext{
funkcji.

${ }^{2}$ Region miejski Nowosybirska obejmuje południowo-wschodnią część Obwodu.
}

1 Zmiany liczby ludności przyjęto, za A. Suliborskim (1983), za jeden z elementów badania zmian 
fy o słabnących bezpośrednich związków z Nowosybirskiem pozwoliło na określenie kierunkowego profilu regionu miejskiego pod względem badanych cech.

Obszerna literatura na temat geografii Rosji (wówczas ZSRR), ale przede wszystkim prezentująca osiągnięcia radzieckiej geografii, pochodzi głównie z lat 1960. i 1970. W tomach Przeglądu Zagranicznej Literatury Geograficznej, a także Przeglądu Geograficznego znajdują się opracowania dotyczące regionalizacji ekonomicznej w ZSRR (Dziewoński, 1960), geografii przemysłu (Kukliński, 1960 w lit. 1971), zagadnień związanych z procesami urbanizacji (Dawidowicz, 1972; Pokszyszewski, 1972), czy generalnie metodologii badań prowadzonych wówczas w radzieckiej geografii ekonomicznej zgodnie z założeniami wzorca scjentystycznego. Koncentrowano się na dokumentowaniu przestrzennej organizacji społeczeństwa i gospodarki, zróżnicowania poziomu rozwoju i warunków życia ludności. Badania prowadzono głównie w makro- i mezoskali (kraj, region), wykorzystując metody statystyki opisowej i matematycznej, analizy systemowej, modelowania zjawisk i procesów.

Wśród współczesnych, nielicznych opracowań polskich geografów poświęconych Rosji, ze szczególnym uwzględnieniem zagadnień demograficznych i gospodarczych, dominują publikacje przekrojowe, oparte na danych statystycznych (por. Eberhardt, 2002; Maryański, 1995; Maryański i inni, 1996). Na tym tle wyróżnia się opracowanie T. Witesa (2007), do którego odwoływano się w niniejszym artykule. Jest to monografia problemowa, w której autor powołuje się nie tylko na oficjalne dane demograficzne, lecz także na własne obserwacje z regionów o największej depopulacji w Federacji Rosyjskiej. Istotna jest tutaj zmiana skali badanych zjawisk, a także przejście z poziomu matematycznych i geometrycznych abstrakcji do poziomu sensów i znaczeń w wyjaśnianiu podjętego w pracy problemu.

Metodologia badań prezentowanych w artykule odnosi się do koncepcji funkcjonalnej, rozwijanej w geografii ekonomicznej od lat 1940. (Dziewoński, 1971; Jerczyński, 1973; Suliborski, 1983, 2010). W tym przypadku skoncentrowano się na dwóch sposobach określania roli (funkcji) miast w krajowym systemie osadniczym, tj.:

- badaniach genezy rozwoju funkcji, w których uwaga skoncentrowana jest na ewolucji (historii) rozwoju funkcjonalnego miast rozpatrywanego jako proces dziejowy. Badania w tym zakresie polegają na specyficznym „czytaniu” historii miasta i jego mieszkańców, w której można dokonać wydzielenia pewnych etapów w odniesieniu do czynników funkcjonalnych, procesów przemian funkcji, instytucji odpowiedzialnych za ich istnienie oraz efektów w postaci określonej struktury funkcjonalnej;

- badaniach funkcji wyspecjalizowanych, których celem jest określenie bazy ekonomicznej (funkcji egzogenicznych) jednostek terytorialnych. Baza ekonomiczna stanowi sektor działalności w danym mieście, który odpowiedzialny jest za wytworzenie związków z jego otoczeniem, a tym samym powstawanie systemu osadniczego państwa (Suliborski, 2001, 2010). 


\section{Geneza rozwoju funkcji aglomeracji Nowosybirska}

Rozwój każdego miasta wiąże się ściśle ze spełnianiem określonych funkcji dominujących, których rodzaj oraz dynamika zmian formują jego specyfikę społeczną i przestrzenną (Jewtuchowicz i Suliborski, 2009). Funkcje stanowią główne atrybuty miasta, a wszelkie ich zmiany są efektem działania rozmaitych czynników sprawczych, określanych przez A. Suliborskiego (2010) mianem czynników funkcjonalnych. Rozpoznanie i analiza dynamiczna czynników funkcjonalnych oraz desygnatów określonych funkcji w postaci instytucji powoływanych do wykonywania określonych działalności, form zagospodarowania przestrzeni czy zachowań społecznych (zawodowych), umożliwia identyfikację funkcji występujących w mieście w danym czasie i formułowanie uogólnień dotyczących procesów i faz funkcjonalnych, jakie przechodziło miasto w swojej historii.

W tej części opracowania zaprezentowano model kształtowania się funkcji i struktury funkcjonalnej Nowosybirska, na który składają się: czynniki funkcjonalne i związane z nimi procesy oraz fazy funkcjonalne o określonych funkcjach dominujących. Ponieważ pojęcie funkcji odnosi się bezpośrednio do form wykorzystania i użytkowania terenu, w analizie uwzględniono także problematykę morfologiczną, zwracając uwagę na formy najbardziej charakterystyczne dla poszczególnych faz rozwoju funkcjonalnego miasta.

Dzieje funkcjonalne Nowosybirska omówiono wyznaczając trzy procesy formujące strukturę funkcjonalną miasta i sześć stadiów uogólniających charakter i zachowanie najważniejszych funkcji. Cechą charakterystyczną w tym przypadku jest uwarunkowanie zmian przede wszystkim czynnikami zewnętrznymi, które zazwyczaj powodują bardzo silną dynamikę procesów funkcjonalnych. Historia Nowosybirska pokazuje, jak sekwencja decyzji podejmowanych przez władze centralne doprowadziła do powstania wewnątrz syberyjskiej tajgi najsilniejszego regionu miejskiego azjatyckiej części Rosji.

Pierwszy etap związany był z kolonizacją Syberii przez Rosjan, która miała miejsce w XVII i XVIII w. Na obszarze zajmowanym współcześnie przez Nowosybirsk istniał wówczas szereg osad o funkcjach rolniczych, rzemieślniczych i handlowych. Pod koniec XIX w. car Aleksander III wydał decyzję o przeprowadzeniu tędy głównej linii kolei transsyberyjskiej (stacja Ob). Dzięki niezwykle korzystnemu położeniu geograficznemu - na skrzyżowaniu ważnych szlaków komunikacyjnych: linii kolei transsyberyjskiej (łączącej Syberię i europejską część Rosji) i przy żeglownej rzece Ob, łączącej północ i południe Syberii, Nowonikołajewsk (później Nowosybirsk - osiedle na prawym brzegu rzeki), szybko się rozwijał i już w 1903 r. otrzymał prawa miejskie. Most kolejowy na rzece Ob wyznaczał główną oś kompozycyjną miasta - Nowonikołajewski Prospekt (dziś Krasnyj Prospekt), wzdłuż którego wytyczono plac targowy i regularne działki pod zabudowę (Nevzgodin, 2005) (ryc. 2). Kolej transsyberyjska wymagająca ciągłej rozbudowy 
stanowiła bardzo ważny czynnik rozwoju przemysłu w mieście. Powstały zakłady zajmujące się budową maszyn rolniczych i przetwórstwem rolno-spożywczym.

Po okresie destabilizacji politycznej i gospodarczej, związanej z rewolucjami i wojną domową w Rosji w latach 1917-1920, nadszedł etap dynamicznego rozwoju miasta związany z Nową Polityką Ekonomiczną W. Lenina oraz rządami J. Stalina. Inwestowano w infrastrukturę kolejową (powstały nowe połączenia miasta z południem kraju i Kuźnieckim Zagłębiem Węglowym), w przemysł, wybudowano nowy port. Jednocześnie powstawały budowle użyteczności

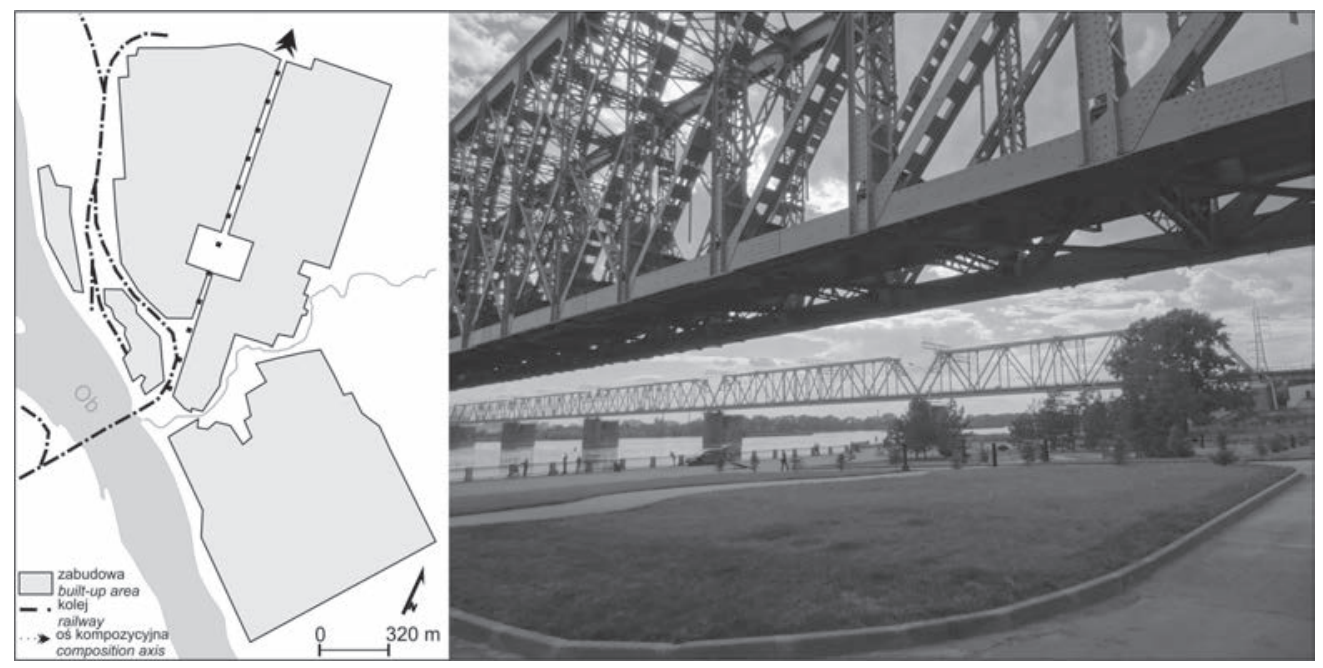

Ryc. 2. Struktura przestrzenna Nowosybirska w 1906 r. i mosty kolejowe na rzece Ob. Na pierwszym planie przęsło mostu z $1893 \mathrm{r}$.

Na podstawie: http://nsk.novosibdom.ru/; fot. P. Tobiasz-Lis

The spatial structure of Novosibirsk in 1906 and the railway bridges over the Ob. In the foreground is the span of the bridge from 1893.

Based on: http://nsk.novosibdom.ru/; photo: P. Tobiasz-Lis

publicznej, rozpoczęto budowę pierwszej linii tramwajowej w mieście. Gwałtowny wzrost liczby ludności wymuszał masowe inwestycje w budownictwo mieszkaniowe. Władze inwestowały też w edukację. Miasto rozbudowywało się w stylu powoli rodzącego się realizmu socjalistycznego. Dominowały szerokie trakty i ogromne place, z założenia skupiające życie mieszkańców. We wznoszonych budynkach stosowano wiele rozmaitych elementów zdobniczych, które nadawały im monumentalny charakter (Nevzgodin, 2005). W tym okresie, wraz z rozbudową regionalnych powiązań kolejowych, prawa miejskie otrzymały osiedla wiejskie wokół Nowosybirska, m.in.: Czerepanowo (1925), Berdsk (1929) i Iskitim (1938) - o dominujących funkcjach przemysłowych (wydobycie surowców skal- 
nych, przemysł mineralny, budownictwo, przemysł spożywczy), tworząc zalążki regionu miejskiego.

Kolejnym okresem dynamicznego rozwoju Nowosybirska w warunkach komunistycznej gospodarki centralnie planowanej, były lata 1941-1945, kiedy do miasta ewakuowano ponad 300 zakładów przemysłowych z zachodnich części ZSRR. Profil produkcyjny zmienił się z przemysłu lekkiego na przemysł ciężki (związany głównie z zakładami zbrojeniowymi). Większość zakładów działających w czasie wojny funkcjonowało w stanie prowizorycznym, zajmując często budynki użyteczności publicznej - szkoły czy świątynie. Dynamiczny rozwój funkcji przemysłowych odbywał się kosztem recesji innych funkcji miejskich zwłaszcza komunalnych (mieszkaniowych), kulturalnych i edukacyjnych.

Po II wojnie światowej, w okresie zimnej wojny i wyścigu zbrojeń, plany władz centralnych ZSRR zakładały dalszy rozwój Nowosybirska jako głównego ośrodka przemysłu ciężkiego i inżynierii procesowej (Seth, 2007). W tym celu rozpoczęto modernizację już istniejących fabryk oraz budowę nowych, związanych przede wszystkim z przemysłem zbrojeniowym. Miasto stało się ważnym ośrodkiem przemysłu maszynowego, elektronicznego, chemicznego oraz hutnictwa i górnictwa. Nagromadzenie wielkich zakładów przemysłowych wymagało stworzenia bazy naukowej i badawczej. Poza działającym już Syberyjskim Oddziałem Akademii Nauk ZSRR, utworzono szereg wyspecjalizowanych szkół wyższych. W 1957 r. Rada Ministrów ZSRR zatwierdziła plany powołania centrum naukowego Akademgorodok, które skupiło ponad 40 instytutów badawczych, Państwowy Uniwersytet, a także zaplecze mieszkaniowe dla naukowców i studentów oraz bogatą infrastrukturę społeczną. Doprowadziło to do wyraźnego rozwoju funkcji naukowych, mieszkaniowych i oświatowych miasta. W tym samym roku uruchomiono nowy port lotniczy Tołmaczewo, który dodatkowo wzmocnił strategiczne, pod względem komunikacyjnym, położenie miasta. Lata 1960. i 1970. przyniosły intensywną rozbudowę terenów mieszkaniowych związaną z rozwojem technologii prefabrykatów i infrastruktury technicznej oraz społecznej Nowosybirska $\mathrm{i}$ innych miast $\mathrm{w}$ jego aglomeracji. Tworzono parki, tereny zielone i rekreacyjne, rozpoczęto budowę metra. W latach 1980. nastąpiło spowolnienie gospodarcze i koniec wielkich inwestycji.

Przemiany polityczne i gospodarcze lat 1990. związane z rozpadem ZSRR i przejściem do gospodarki kapitalistycznej doprowadziły do zamknięcia wielu zakładów i fabryk oraz do nieznanego wcześniej bezrobocia o dużej skali. Obecnie Nowosybirsk odbudowuje swoje dawne znaczenie. Miasto jest administracyjnym centrum Obwodu Nowosybirskiego i Syberyjskiego Okręgu Federalnego. Obok potężnych zakładów przemysłowych, w mieście dynamicznie rozwija się sektor usług - przede wszystkim usługi dla producentów i biznesu, a także handel. Proces dostosowywania struktury funkcjonalnej miasta do nowych uwarunkowań politycznych i gospodarczych widać także w mikroskali, w samym centrum naukowym i badawczym Akademgorodok, które rozbudowuje się dzięki napły- 


\section{CZYNNIKI FUNKCJONALNE}

FUNCTIONAL FACTORS
PROCESY KSZTAKTUJACE FUNKCJE I STRUKTURE, FUNKCJONALNA NOWOSYBIRSKA ORAZ ODPOWIADAJACE IM FAZY FUNKCJONALNE

PROCESSES THAT SHAPE THE FUNCTIONS WITH THEIR CORRESPONDING FUNCTIONAL PHASES

- colonisation of Siberia by the Russian population in the 17th and 18th century - trade with Teleuts inhabiting the right bank of the Ob River

- construction of defensive fortresses (Tomsk, Berdsk)

- decyzja o budowie mostu na rzecze Ob w okolicy osady Kriwoszczekowo
i wytyczeniu trasy kolei transsyberyjskiej (1893 r.)
- budowa soboru Sw. Aleksandra Newskiego (1895 r.)
- nadanie praw miejskich osadzie Nowo-Nikolajewsk (1903 r.)
- decision to build a bridge over the Ob River near the village of Krivoshchyokovo
and route the Trans-Siberian Railway (1893)
- construction of the Cathedral of Saint Alexander Nevsky (1895)
- town rights given to Novonikolayevsk (1903)

- rewolucja lutowa (1917 r.) - nacjonalizacja majątków i przemysłu w mieście
- 1917-1920 - wojna domowa
- February Revolution (1917) - nationalisation of property and industry in the city
-1917-1920 - Civil War

\section{- Nowa Polityka Ekonomiczna W. Lenina (1921-1929)}

- polączenia kolejowe z południowymi terenami ZSRR (linia kolejowa

Turkiestan - Syberia) oraz Kuźnieckim Zagłębiem Weglowym

- polityka kolekwtywizacji wsi J. Stalina

- railway connections with the southern areas of the USSR (Turkestan - Siberia railway) and the Kuznetsk Coal Basin

-the policy of collectivisation of J. Stalin

\section{- II wojna światowa - atak Niemiec na ZSRR w 1941 r.}

- ewakuacja ponad 300 zakładów produkcyjnych z zachodnich części ZSRR (10\% produkcji przemysłowej)

- Wasowe przymusowe deportacje ludności

- evacuation of more than 300 production plants from the western part of the SU (10\% of industrial production)

- mass forced depertations

powojenny plan stworzenia w rejonie Nowosybirska centrum ciężkiego przemysłu oraz inżynierii

uruchomienie portu lotniczego Tolmaczewo

stworzenie bazy naukowo-badawczej - powołano wyspecjalizowane szkoły wyższe,

rozwój Syberyjskiego Oddziału Rosyjskiej Akademii Nauk

- postwar plan to create a centre of heavy industry and engineering in the region

of Novosibirsk

commissioning of the Tolmachevo airport

creation of a scientific and research base with specialisedinstitutions of higher

education, the development of the Siberian Branch of the Russian Academy of Sciences

\section{- kryzys i rozpad ZSRR (przemiany gospodarcze i społeczne: likwidacja części} zakładów, zjawisko bezrobocia)

- crisis and the collapse of the Soviet Union (economic and social transformations: closure of some plants, unemployment)
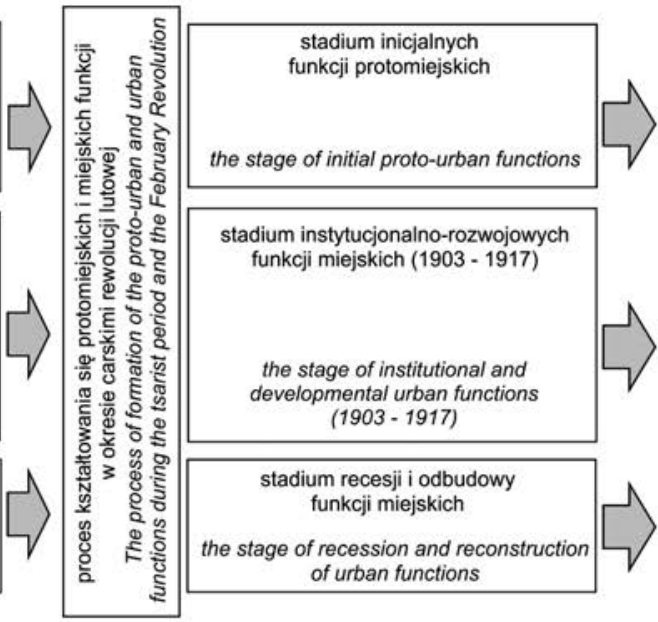

rolnicza, rzemieślnicza, handlowa, usługowa

agricultural, craft, trade, service

stadium instytucjonalno-rozwojowych
funkcji miejskich (1903 - 1917)
the stage of institutional and
developmental urban functions
(1903 - 1917)

komunikacyjna, handlowa, rolnicza, zemieślnicza, usługowa, administracyjna przemysłowa (spożywczy, maszynowy)

communication, commercial, agricultural, craft, service, administrative industrial (food, machines)

stadium recesji i odbudowy
funkcji miejskich
the stage of recession and reconstruction
of urban functions

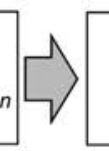

przemysłowa, komunikacyjna, rzemieślnicza, handlowa, usługowa, administracyjna industrial, communication,
craft, trade, service, administrative
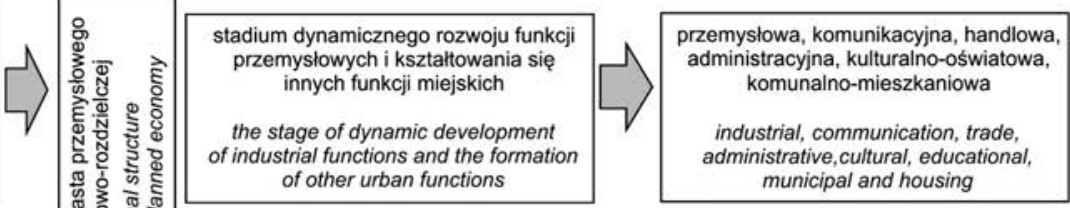

stadium rozwoju funkcii przemyslowych na potrzeby dzialan wojennych kosztem recesji innych funkcji miejskich the stage of development of industrial functions for wartime purposes at the expense of the recession of other urban functions

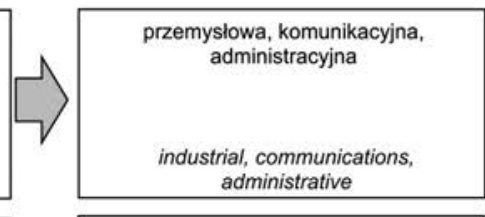

stadium dominacji funkcji przemysłowych i rozwoju nowych funkcji wspomagających przemys

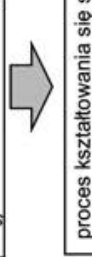

the stage of the dominance of industrial
functions and the development of
new functions that support the industry

przemystowa (zbrojeniowy, maszynowy,
elektroniczny, hutniczy, chemiczny, górnictwo),
komunikacyjna,handlowa,naukowa,
kulturalno-oswiatowa,
komunalno-mieszkaniowa, administracyjna
industrial (defense, machinery, electronics,
metallurgy, chemicals, mining),
communication, commercial,
scientific, cultural and educational,
municipal and housing, administrative

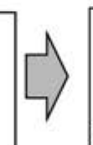

proces dostosowania struktury funkcjonalnej miasta do nowych uwarunkowań polityczno-gospodarczych

the process of adapting the functional structure of the city to the new political and economic conditions przemysłowa (maszynowy, elektroniczny, lotniczy, chemiczny, hutniczy, skórzano-odzieżowy),

usługowa (naukowe, kulturalno-oświatowe finansowe, ubezpieczeniowe) komunikacyjna, handlowa, administracyjna

industrial (machinery, electronics, aerospace, chemical, metallurgy, leather and clothing), services (scientific, cultural, educational, financial, insurance), communication, trade

Ryc. 3. Model procesów przemian funkcji i struktury funkcjonalnej Nowosybirska A model for processes of transformation of Novosibirsk's functions and functional structure 
wowi kapitału zagranicznego i nowym inwestycjom związanym z przemysłem wysokich technologii. W 2006 r. z inicjatywy Syberyjskiego Oddziału Rosyjskiej Akademii Nauk oraz władz miasta i obwodu, powstał technopark wspierający innowacyjne przedsiębiorstwa.

Przemiany struktury funkcjonalnej aglomeracji Nowosybirska wobec nowych uwarunkowań politycznych i gospodarczych po 1991 r. znalazły bezpośrednie odzwierciedlenie w strukturze przestrzennej całego regionu miejskiego. Przestrzeń poddana prawom rynku zmienia się w wymiarze zarówno ilościowym, jak i jakościowym. Powstały nowe formy zabudowy takie jak: centra handlowe, banki, biurowce, związane głównie z napływem kapitału zagranicznego, które poprzez lokalizację w centrach miast często stanowią kontrast wobec istniejącej - XIX- i XX-wiecznej zabudowy. Równolegle następuje rozwój terenów mieszkaniowych, który odzwierciedla nowe uregulowania prawne w postaci wolnego rynku nieruchomości, a także rosnące zapotrzebowanie na zabudowę mieszkaniową o podwyższonym standardzie, czy potrzebę odizolowania od otoczenia. W rezultacie, osiedla mieszkaniowe budowane w latach 1970. w technologii wielkiej płyty, a będące symbolem polityki egalitaryzmu, ulegają stopniowej dekapitalizacji, na obrzeżach miast powstają zaś nowe inwestycje mieszkaniowe w postaci osiedli grodzonych. Nowe formy zabudowy w przestrzeni miast aglomeracji Nowosybirska powodują wzrost jej mozaikowości, ale jednocześnie zmniejszają dystans pod względem wyglądu i funkcjonowania do miast zachodnioeuropejskich.

\section{Potencjał demograficzny regionu i jego zmiany}

Według danych służb statystycznych Federacji Rosyjskiej, w Obwodzie Nowosybirskim mieszkało w 2012 r. 2709461 osób, co stanowiło 1,9\% ludności całego kraju. Ponad połowa populacji obwodu (1 498921 osób) mieszkała w jego stolicy - Nowosybirsku, który jest trzecim co do wielkości miastem Rosji, a jednocześnie najbardziej odległym od Moskwy „milionowym” miastem w państwie. Zmiany liczby ludności w poszczególnych ośrodkach miejskich regionu należy wiązać z opisanymi wyżej decyzjami politycznymi, podejmowanymi w różnych okresach historycznych. Ich przebieg nie był naturalny - zarówno liczba, jak i rozmieszczenie ludności były sterowane przez władze państwowe w konsekwencji polityki systematycznego zagospodarowania Syberii i Dalekiego Wschodu. W świadomości społecznej tereny te kojarzone były z szansą rozwoju, zmianą dotychczasowych warunków życia, nadzieją, ale i obawą przed nieznanym. Po okresie dynamicznego zaludniania w okresie sowieckim, przemiany gospodarcze po rozpadzie ZSRR doprowadziły do procesów depopulacyjnych całego regionu (Wites, 2007). W obwodzie nowosybirskim, ze względu na jego położenie w południowo-wschodniej części azjatyckiej Rosji, o stosunkowo sprzyjających warunkach środowiska, wysokim stopniu uprzemysłowienia i zurbanizowania, 
negatywne tendencje depopulacyjne początku okresu transformacji gospodarczej w Federacji Rosyjskiej (spadek liczby ludności do 2640000 w 2007 r.), w ostatnich latach systematycznie się zmieniają. Analiza zmian liczby ludności w dłuższej perspektywie czasowej, w poszczególnych ośrodkach regionu Nowosybirska pozwala zaważyć kilka istotnych prawidłowości.

W przypadku wszystkich ośrodków, w okresie do 1917 r. można mówić o kolonizacji rolniczej, której natężenie wzrosło po przeprowadzeniu tędy odcinka kolei transsyberyjskiej (Maryański, 1995 za: Wites, 2007). Ta inwestycja spowodowała, że Nowonikołajewsk (później Nowosybirsk) zajął centralną pozycję w kształtującym się regionie miejskim. W kolejnych dekadach okresu Rosji sowieckiej, w wyniku zarówno dobrowolnych, jak i przymusowych migracji, zwłaszcza w okresie totalitarnych rządów J. Stalina, liczba ludności Nowosybirska wzrosła niemal dziesięciokrotnie - z około 70000 mieszkańców w 1917 do 640000 w 1950 r. Wzrost zaludnienia miasta wpływał na współczynnik urbanizacji obwodu nowosybirskiego, którego wartość z 15\% w 1926 r. wzrosła do 41\% w 1939. Okres rozwoju Nowosybirska jako centrum przemysłu ciężkiego, wspomaganego przez silne i wyspecjalizowane zaplecze naukowe i badawcze, a więc lata 1951-1991, charakteryzował jeszcze bardziej dynamiczny wzrost populacji miasta. W momencie rozpadu ZSRR, w 1991 r., liczba ludności Nowosybirska wynosiła 1435 000. Po krótkim okresie kryzysu demograficznego, który wystąpił w całej Federacji Rosyjskiej w latach 1990., niekorzystne tendencje odwróciły się i w ostatnich latach centrum aglomeracji miejskiej Nowosybirska charakteryzuje powolny, ale stabilny wzrost liczby ludności. Warto podkreślić, że w okresie rzeczywistego, choć nieznacznego $(4,4 \%)$ w porównaniu z innymi jednostkami Syberii i Dalekiego Wschodu, spadku populacji miasta w latach 1991-1998, saldo migracji było dodatnie, ale nie rekompensowało ubytku naturalnego ludności. W związku z tym odwrócenie procesu depopulacji Nowosybirska i całego regionu miejskiego było znacznie szybsze niż w przypadku innych ośrodków Syberii i Dalekiego Wschodu, gdyż wymagało zmian tylko w ruchu naturalnym ludności, któremu sprzyjała struktura wiekowa nowych, napływowych mieszkańców. W ostatnich latach, poza nieznacznym dodatnim wskaźnikiem przyrostu naturalnego (1\%o w 2011 i 2012 r.), w Nowosybirsku zanotowano wysokie, dodatnie saldo migracji.

Liczbę ludności Berdska, rozwijającego się w bezpośrednim otoczeniu Nowosybirska, charakteryzuje stały wzrost liczby ludności, a jego dynamika nawiązuje wyraźnie do wydarzeń, które decydowały o rozwoju gospodarczym i przestrzennym ośrodka. Największy wzrost liczby ludności nastąpił tutaj po relokacji miasta, która miała miejsce w latach 1953-1958 w związku z budową elektrowni wodnej i sztucznego zbiornika na rzece Ob. Po przeniesieniu Berdska o 8 km od pierwotnej lokalizacji, powstały nowe zakłady przemysłowe (wartość produkcji wzrosła dwukrotnie), rozbudowano zaplecze mieszkalno-bytowe, miasto całkowicie zelektryfikowano. Wszystkie inwestycje doprowadziły do znacznej popra- 


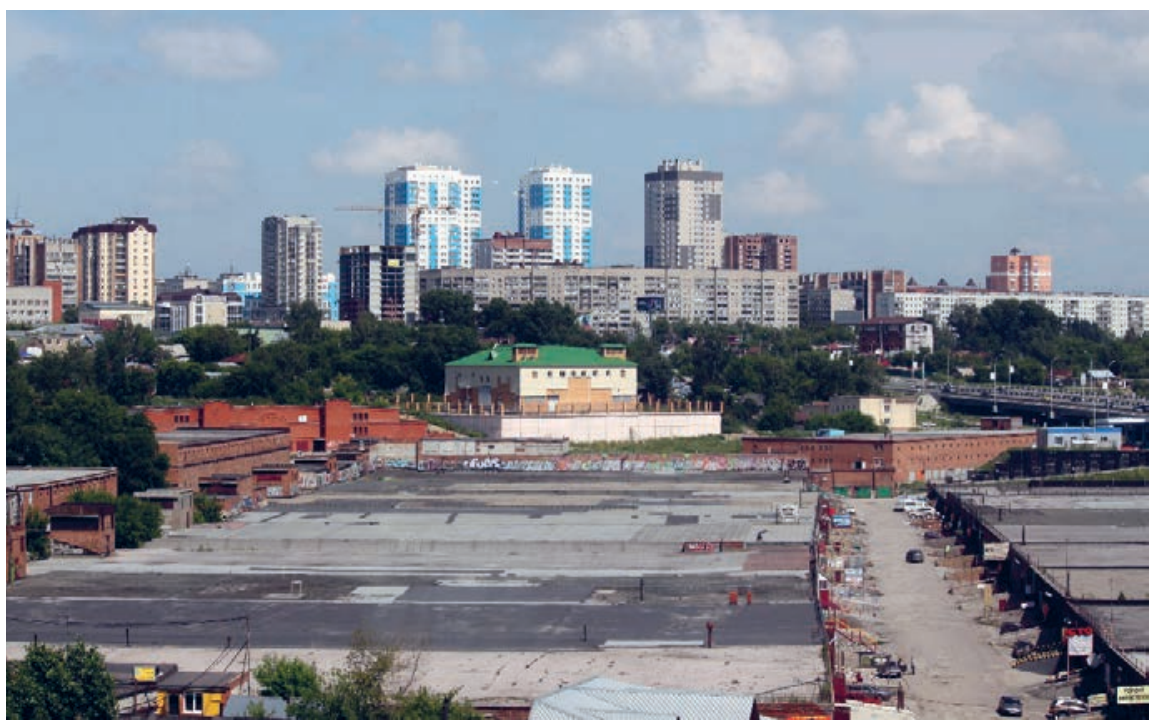

Fot. 1. Nowe i stare formy zabudowy mieszkaniowej w centrum Nowosybirska Fot. (wszystkie): M. Wójcik

New and old forms of housing construction in the centre of Novosibirsk Photographs (all) by M. Wójcik

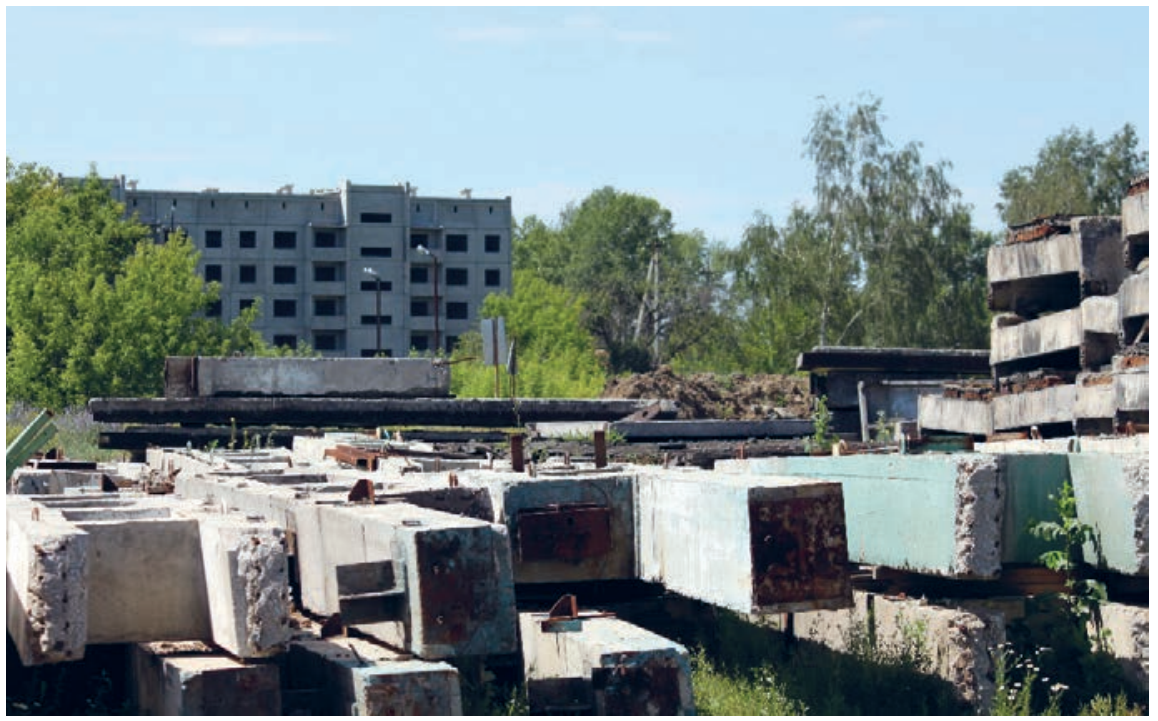

Fot. 2. Zdegradowane obszary przemysłowe w centrum Berdska Degraded industrial areas in the centre of Berdsk 


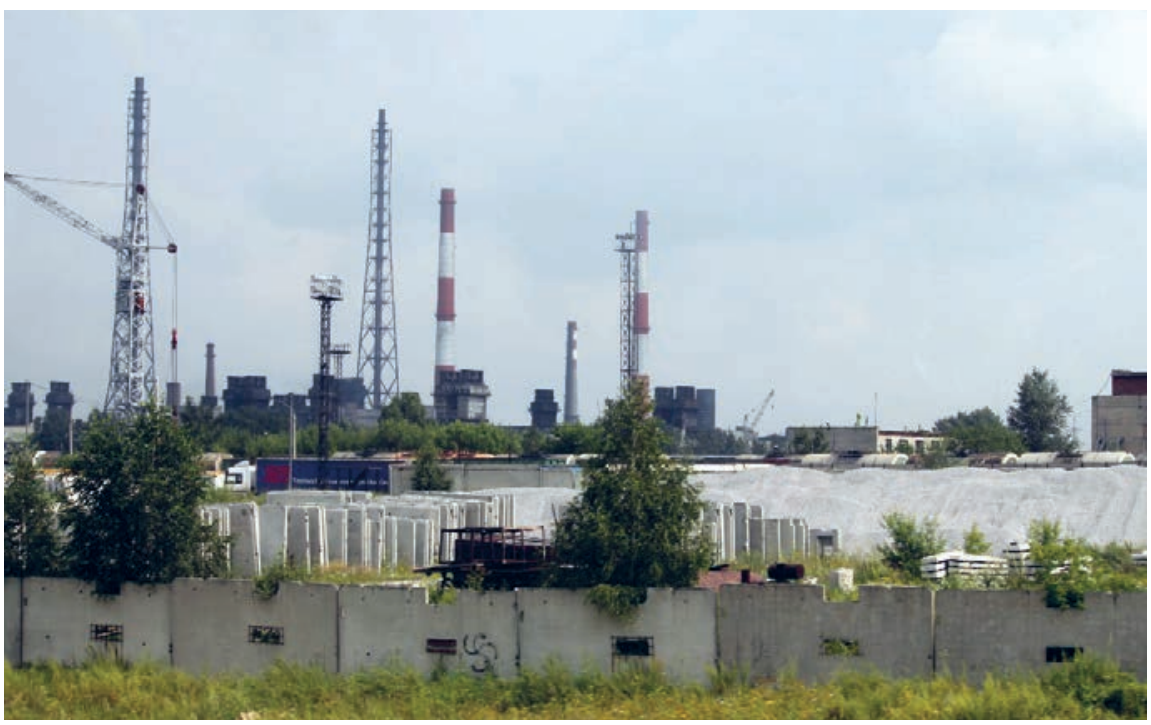

Fot. 3. Przemysłowy krajobraz wzdłuż linii kolejowej Nowosybirsk-Czerepanowo.

Osada robotnicza Linewo

Industrial landscape along the Novosibirsk-Cherepanovo railway line.

The Linevo workers' settlement

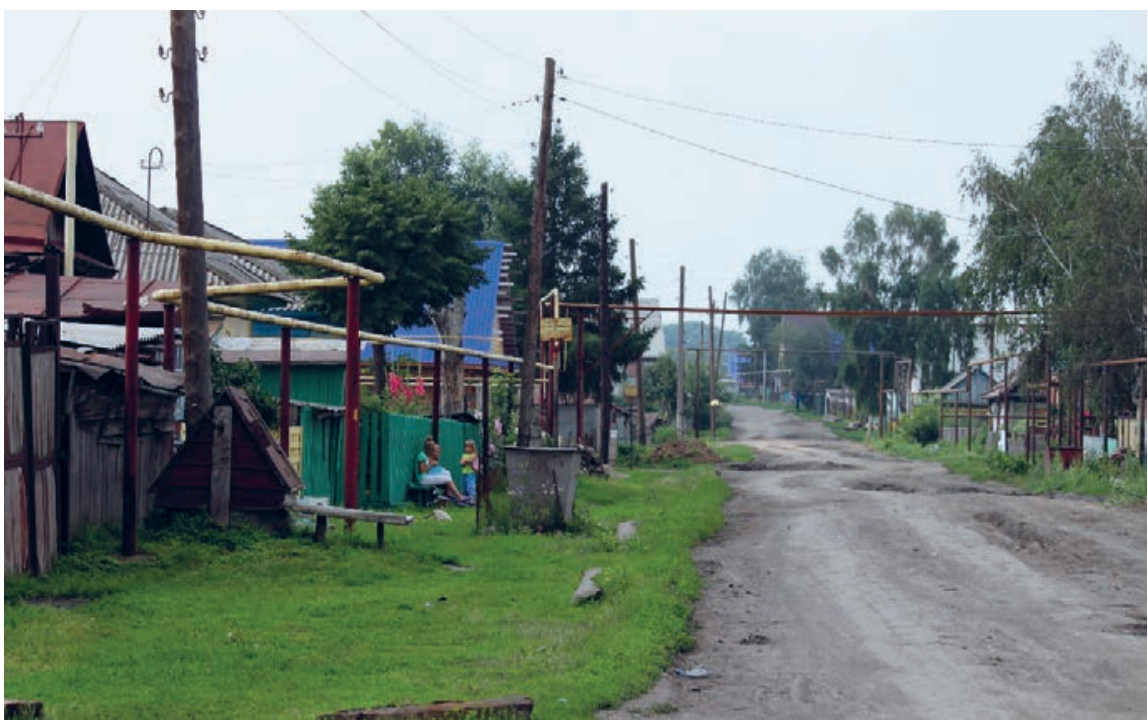

Fot. 4. Obszary mieszkaniowe w ośrodku peryferyjnym - Czerepanowo Residential areas in a peripheral settlement - Cherepanovo 
wy warunków życia ludności, pociągając za sobą dodatnie i przyrost naturalny, i saldo migracji. Zarówno Berdsk, jak i rejon nowosybirski obejmujący tereny okalające Nowosybirsk i część jego przedmieść, będące zapleczem dla centrum aglomeracji wydzielonym w 1939 r., charakteryzuje w ostatnich latach dodatni przyrost naturalny i dodatnie saldo migracji.

Odmiennie kształtują się zmiany liczby ludności ośrodków na terenach poza rdzeniem regionu miejskiego Nowosybirska, związane przede wszystkim z gospodarką rolną i produkcją przemysłową opartą na zasobach środowiska (górnictwo). Wysoka dynamika wzrostu populacji notowana w czasach sowieckich, wywołana polityką forsownej kolektywizacji, uprzemysłowienia, a także masowych deportacji w ramach systemu GUŁag (w rejonie iskitimskim funkcjonował 4-SIBŁag), zdecydowanie zmalała. W ostatniej dekadzie w rejonach iskitimskim i czerepanowskim obserwuje się stały spadek liczby ludności, przede wszystkim w wyniku migracji (ryc. 4).
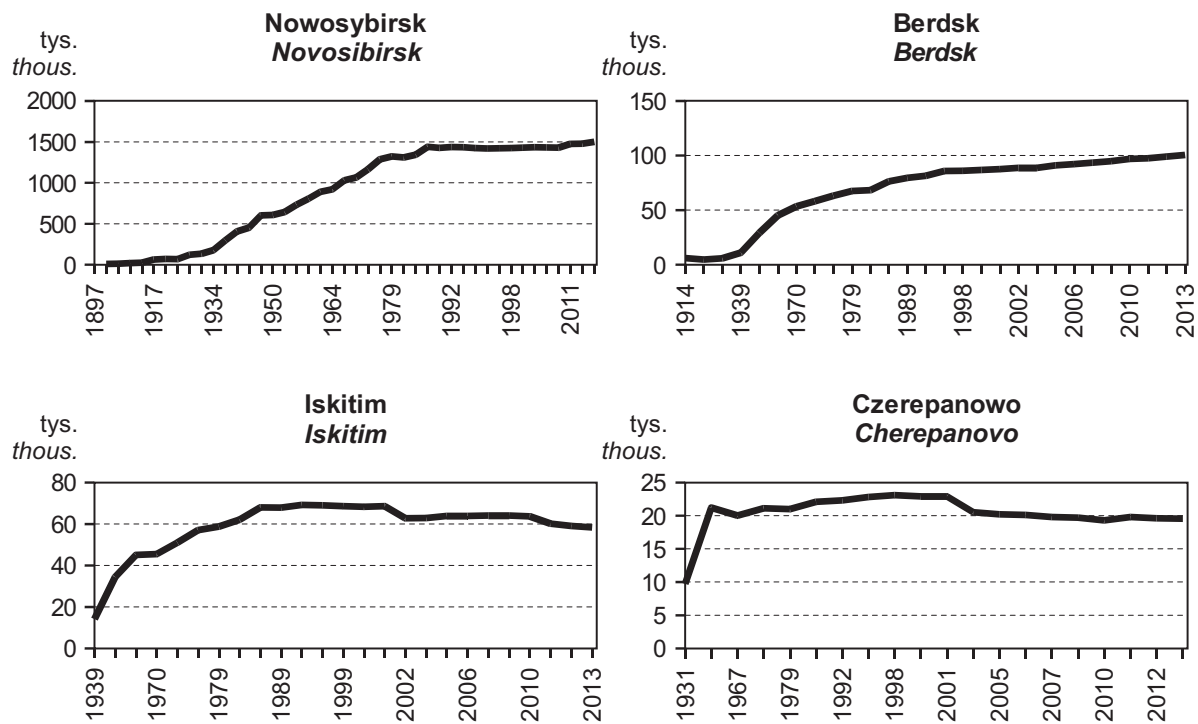

Ryc. 4. Zmiany liczby ludności wybranych miast aglomeracji Nowosybirska.

Na podstawie http://www.gks.ru

Changes in the population of selected cities of the Novosibirsk urban region

Based on: http://www.gks.ru 


\section{Funkcje ekonomiczne w regionie miejskim Nowosybirska}

\section{Metodyka badań}

Jedną z najczęściej stosowanych miar określających rolę miast i innych osiedli w systemach osadniczych jest zatrudnienie w odpowiednich branżach gospodarki. Ponadnormatywne zatrudnienie (powyżej pewnego średniego poziomu) w określonych branżach jest utożsamiane z funkcjami egzogenicznymi. Funkcje egzogeniczne wyznaczają bowiem związki między jednostkami osadniczymi (miastami, aglomeracjami miejskimi) i z tego względu są czynnikiem organizującym system osadniczy państwa (Suliborski, 1983). Identyfikacja funkcji egzogenicznych ma za zadanie wskazanie tych działań gospodarczych i społecznych, które decydują o znaczeniu (roli), a tym samym pozycji (randze) odpowiednich miast lub regionów w społecznym podziale pracy w ramach krajowego systemu osadniczego.

Podstawą metodologiczną tej części opracowania, która dotyczy współczesnych zależności funkcjonalnych wybranych ośrodków w regionie miejskim Nowosybirska, jest koncepcja bazy ekonomicznej. Badania funkcjonalne w myśl założeń koncepcji bazy ekonomicznej wymagają wprowadzenia podziału działalności gospodarczej na dwa sektory - endogeniczny i egzogeniczny. Wielkość sektora egzogenicznego świadczy o sile powiązań jednostki osadniczej z innymi osiedlami. Sektor endogeniczny zaspokaja natomiast potrzeby mieszkańców osiedli. Metodą określenia funkcji egzogenicznych jest, często stosowany dla dużych miast lub zespołów miejskich, pośredni sposób ich identyfikacji zaproponowany przez H. Hoyta, znany pod nazwą metody reszt (residual method) ${ }^{3}$.

\section{Struktura zatrudnienia w rdzeniu regionu miejskiego Nowosybirska}

Badania funkcji regionu miejskiego w myśl założeń koncepcji bazy ekonomicznej przeprowadzono na podstawie oficjalnych danych statystycznych ukazujące wielkość zatrudnienia w podstawowych działach (branżach) gospodarki narodowej w 2012 r. dla wybranych jednostek terytorialnych regionu Nowosybirska oraz Rosji ${ }^{4}$.

${ }^{3}$ Wskaźnik H. Hoyta jest zmodyfikowanym współczynnikiem lokalizacji. Ma on następującą postać:

gdzie:

$$
\mathrm{Z}_{\text {nad } i w}=Z_{i w}-\left(Z_{w} \times Z_{i k} / Z_{k}\right)
$$

$Z_{\text {nad } i w}$ - zatrudnienie nadwyżkowe w działalności $i$ w obszarze $w$,

$Z_{i w}-$ zatrudnienie w działalności $i$ w obszarze $w$,

$Z_{w}^{i w}$ - zatrudnienie całkowite w obszarze $w$,

$Z_{i k}$ - zatrudnienie w działalności $i$ w kraju,

$Z_{k}$ - zatrudnienie całkowite w kraju.

${ }^{4}$ Źródło danych: www.gks.ru. Porównanie dostępnych danych z lat 2010-2012 nie wykazało istotnych różnic ogólnego poziomu i struktury zatrudnienia, a także, w konsekwencji przyjętej procedur badawczej, struktury zatrudnienia egzogenicznego. Identyfikacja bazy ekonomicznej (funkcji egzogenicznych) określonych obszarów opiera się na danych z 2012 r. 
W pierwszej kolejności określono udział rdzenia regionu miejskiego Nowosybirska w zatrudnieniu w podziale na główne branże gospodarki w ogólnym zatrudnieniu w Rosji (tab. 1). Za rdzeń przyjęto, zgodnie ze wstępnymi założeniami, obszar miasta Nowosybirsk oraz obszar bezpośrednio go otaczający (Rejon Nowosybirski), który można utożsamiać ze strefą podmiejską Nowosybirska, o najbardziej ścisłych związkach funkcjonalnych ze stolicą regionu.

W 2012 roku w najbardziej zainwestowanej części, tj. w rdzeniu regionu miejskiego Nowosybirska pracowało około 444 tys. osób. Udział obszaru bezpośrednio otaczającego Nowosybirsk (Rejon Nowosybirski) w ogólnym zatrudnieniu rdzenia wynosił zaledwie około 5\% (udział ludności to mniej więcej 8\%). Pośrednio wskazuje to na występowanie w bliskiej strefie podmiejskiej innych funkcji, których identyfikacja wymaga innego typu informacji (tereny mieszkaniowe, rekreacyjne, podmiejskiego rolnictwa, itd.). Udział zatrudnienia rdzenia regionu miejskiego w ogólnym zatrudnieniu Rosji wyniósł 0,65\%. Jeśli wziąć pod uwage poszczególne branże gospodarki rdzenia regionu miejskiego, widać dość duże dysproporcje (tab. 1). O znaczącej roli rdzenia regionu miejskiego można mówić w przypadku branży, których udział przewyższa ogólny udział tego obszaru w gospodarce państwa (powyżej 0,65\%). Wstępna ocena roli poszczególnych branż gospodarki pokazuje istotną rolę Nowosybirska jako ośrodka koncentrującego ważne funkcje społeczne (tj. administracja publiczna, obrona narodowa i ubezpieczenia społeczne, ochrona zdrowia i opieka społeczna, edukacja), a także te, które zdecydowały o wejściu miasta na określoną ścieżkę rozwoju procesów funkcjonalnych - funkcje miastotwórcze (produkcja przemysłowa, zapatrzenie w energię, gaz i wodę, transport i łączność). O współczesnej roli Nowosybirska informuje przede wszystkim udział zatrudnienia w pośrednictwie finansowym, (najwyższy udział wśród branż) oraz w obsłudze nieruchomości.

W strukturze zatrudnienia, określonej liczbą pracujących w odpowiednich branżach gospodarki, wyraźnie można wstępnie określić funkcjonalne dominanty zwłaszcza dwóch wielkich grup zatrudnienia. Pierwsza związana jest z działalnością instytucji związanych z funkcjonowaniem państwa, regionu, lokalnych struktur władzy oraz branż finansowanych ze środków publicznych, zaspokajających potrzeby ogólnospołeczne. Działalności znajdujące się w obrębie edukacji, ochrony zdrowia i opieki społecznej, administracji publicznej, obrony narodowej i ubezpieczeń społecznych stanowiły w 2012 r. około 34\% ogólnej liczby pracujących w rdzeniu regionu miejskiego (444 tys. pracujących). Branże, które wyznaczyły rozwój Nowosybirska, czyli produkcja przemysłowa (włączając $\mathrm{w}$ to wytwarzanie i zaopatrywanie $\mathrm{w}$ energię oraz budownictwo), stanowiły łącznie blisko 25\% zatrudnionych. Do tego należy uwzględnić około 9\% pracujących w obsłudze transportu i łączności. Dynamiczne funkcje usługowe okresu przemian związanych z transformacją gospodarczą koncentrowały w 2012 r. około 20\% pracujących, głównie w handlu i naprawach oraz pośrednictwie finansowym. 
Tabela 1. Udział zatrudnienia rdzenia regionu miejskiego w ogólnym zatrudnieniu Federacji Rosyjskiej

The share of total employment in the Russian Federation accounted for by the cores of urban regions

\begin{tabular}{|l|c|c|c|}
\hline \multicolumn{1}{|c|}{$\begin{array}{c}\text { Bector of the economy } \\
\text { Branża gospodarki }\end{array}$} & $\begin{array}{c}\text { Nowosybirsk } \\
\text { i Rejon } \\
\text { Nowosybirski } \\
\text { Novosibirsk } \\
\text { City and } \\
\text { Novosibirsk } \\
\text { Municipal } \\
\text { District }\end{array}$ & $\begin{array}{c}\text { Federacja } \\
\text { Rosyjska } \\
\text { Russian } \\
\text { Federation }\end{array}$ & $\begin{array}{c}\text { Udział (\%) Nowosybir- } \\
\text { ska i Rejonu Nowosy- } \\
\text { birskiego w Federacji } \\
\text { Rosyjskiej }\end{array}$ \\
$\begin{array}{l}\text { Share (\%) of Novosibirsk } \\
\text { City and Novosibirsk } \\
\text { Municipal District in } \\
\text { the Russian Federation }\end{array}$ \\
\hline A - rolnictwo, łowiectwo, leśnictwo & 3441 & 6428000 & 0,05 \\
B - rybołówstwo i hodowla ryb & 79 & 142000 & 0,06 \\
C - górnictwo & 338 & 1068000 & 0,03 \\
D - produkcja przemysłowa & 76599 & 10230000 & $\mathbf{0 , 7 5}$ \\
E - zaopatrzenie w energię, gaz i wodę & 19402 & 1960000 & $\mathbf{0 , 9 9}$ \\
F - budownictwo & 14508 & 5581000 & 0,26 \\
G - handel i naprawy & 44650 & 12400000 & 0,36 \\
H - hotele i restauracje & 3888 & 1250000 & 0,31 \\
I - transport i łączność & 40537 & 5381000 & $\mathbf{0 , 7 5}$ \\
J - pośrednictwo finansowe & 18909 & 1215000 & $\mathbf{1 , 5 6}$ \\
K - obsługa nieruchomości & 54153 & 5657000 & $\mathbf{0 , 9 6}$ \\
L - administracja publiczna, obrona & 44618 & 3760000 & $\mathbf{1 , 1 9}$ \\
narodowa; ubezpieczenia społeczne & & & $\mathbf{1 , 0 0}$ \\
M - edukacja & 56934 & 5711000 & $\mathbf{1 , 0 8}$ \\
N - ochrona zdrowia i opieka społeczna & 49662 & 4597000 & 0,64 \\
O - inne usługi komunalne i społeczne & 16107 & 2532000 & 0,65 \\
\hline Zatrudnienie ogółem & 443825 & 67912000 & \\
Total employment & & & \\
\hline
\end{tabular}

Opracowanie własne. / Authors' own elaboration.

Reasumując można stwierdzić, że struktura ekonomiczna wielkiego ośrodka miejskiego - rdzenia regionu jest $\mathrm{w}$ tym wypadku trójdzielna i obejmuje prawie równorzędne sektory produkcji przemysłowej (wraz z transportem), usług publicznych oraz usług komercyjnych. W stosunku do podobnych pod względem metodycznym badań prowadzonych np. nad regionem miejskim Łodzi (Polska), bardzo doświadczonym przez procesy transformacji społeczno-ekonomicznej, należy zauważyć, że w przypadku Nowosybirska nie doszło do drastycznego spadku zatrudnienia w przemyśle. Podobieństwo odnosi się natomiast do dużego znaczenia zatrudnienia $\mathrm{w}$ administracji publicznej, w mniejszym zakresie innych usług publicznych. 


\section{Struktura zatrudnienia w strefie peryferyjnej regionu miejskiego Nowosybirska - przykład obszaru wzdłuż linii kolejowej Nowosybirsk-Czerepanowo}

Biorąc pod uwagę dane dotyczące wielkości zatrudnienia w jednostkach administracyjnych położonych wzdłuż linii kolejowej Nowosybirsk-Czerepanowo (tzn. Berdsk, Iskitim i Czerepanowo), można zauważyć ich niewielki potencjał społeczno-gospodarczy w stosunku do rdzenia regionu miejskiego (ryc. 5). W sumie w tych trzech jednostkach pracowało około 51 tys. osób (Berdsk - 15 tys., rejon iskitimski i Iskitim - około 26 tys., rejon czerepanowski - 9,8 tys.).

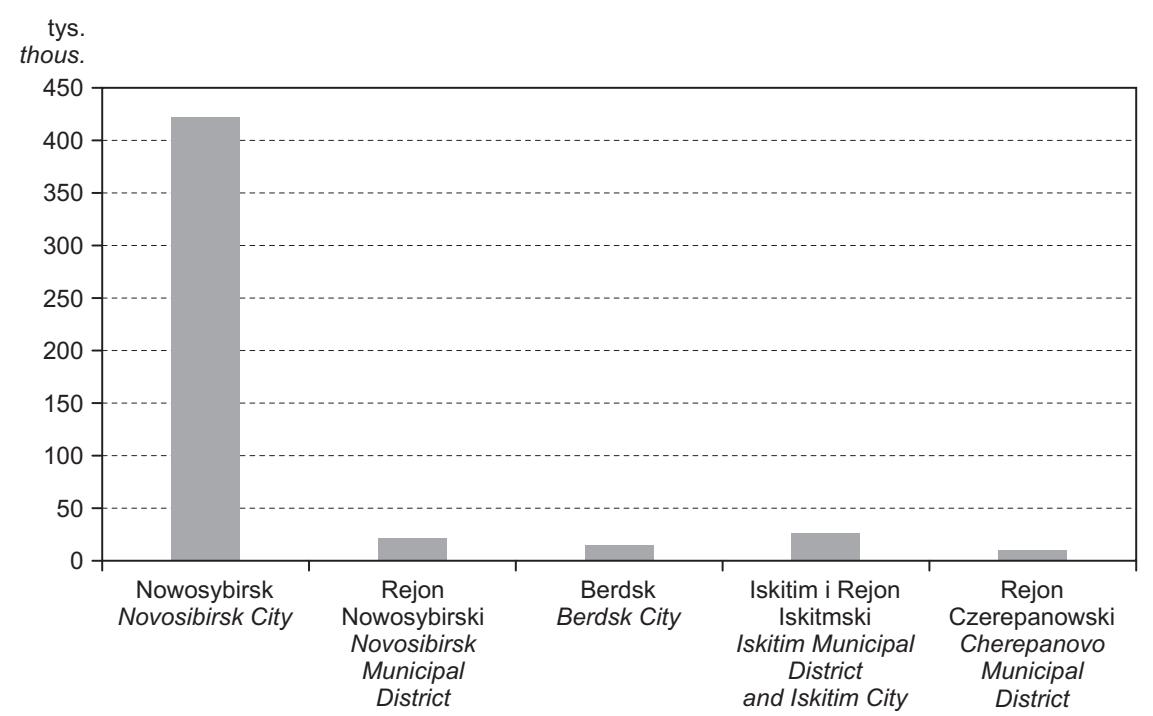

Ryc. 5. Wielkość zatrudnienia w badanych jednostkach regionu miejskiego Nowosybirska w $2012 \mathrm{r}$.

Employment levels in studied administrative units of the Novosibirsk urban region in 2012

Podstawową różnicą $\mathrm{w}$ stosunku do przedstawionej wcześniej struktury zatrudnienia $\mathrm{w}$ rdzeniu regionu miejskiego, jest zwiększenie roli zatrudnienia w branżach produkcyjnych, zwłaszcza przemysłu przetwórczego i wydobywczego. Większe znaczenie pod tym względem mają również działalności ogólnopubliczne (utrzymywane przez państwo), tj. administracja, obrona narodowa, edukacja czy ochrona zdrowia. Wobec dominacji tych dwóch grup działalności niewielki udział mają formy zatrudnienia związane z usługami komercyjnymi handel, naprawy, działalność finansowa i biznesowa (ryc. 6). 
$\%$

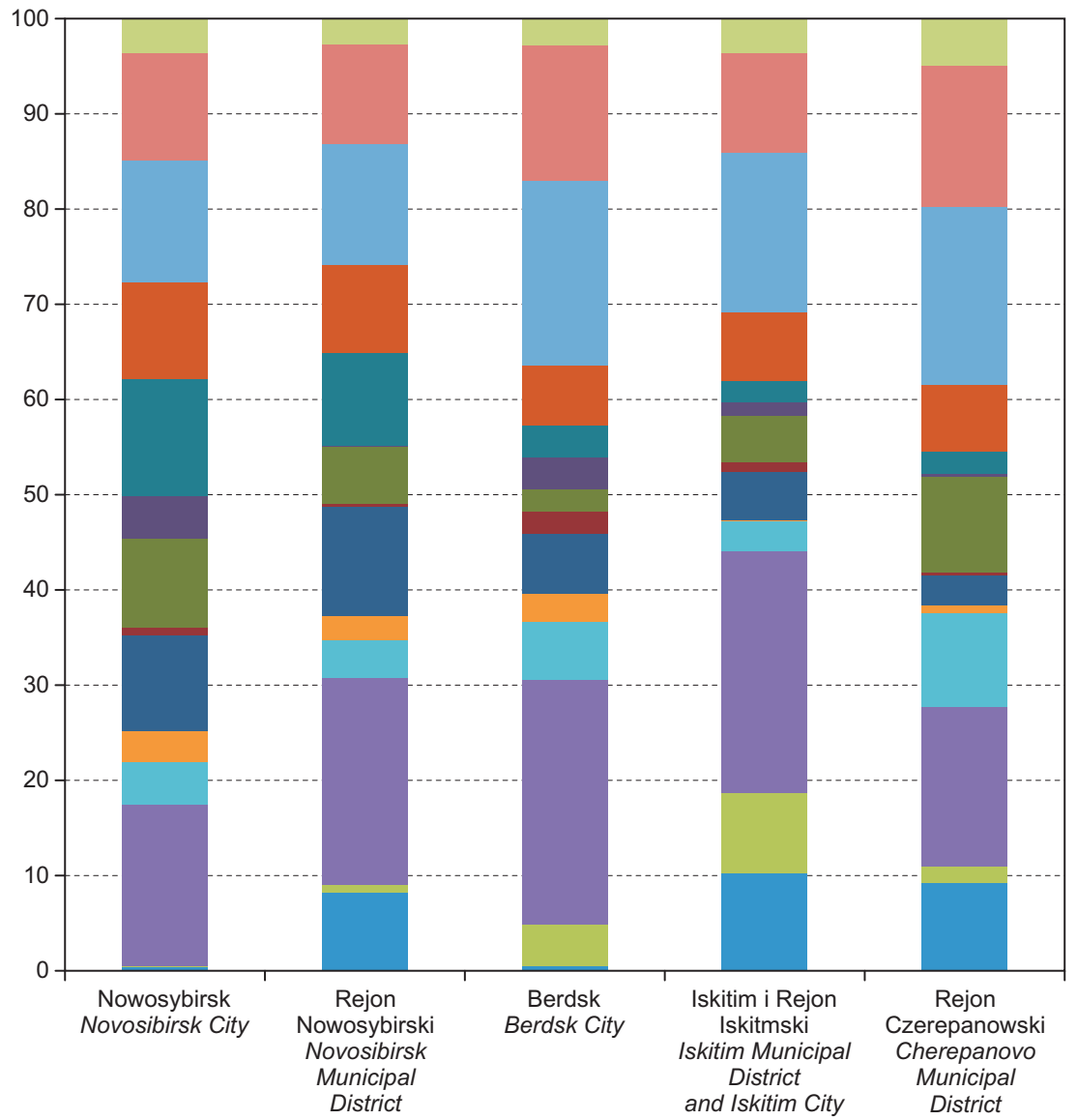

inne usługi komunalne i społeczne / other community, social and personal service activities

ochrona zdrowia i opieka społeczna / health and social work

edukacja / education

administracja publiczna, obrona narodowa i ubezpieczenia społeczne public administration and defence, compulsory social security

obsługa nieruchomości / real estate, renting and business activities

a pośrednictwo finansowe / financial intermediation

- transport i łączność / transport and communication

- hotele i restauracje / hotels and restaurants

handel i naprawy / retail trade and repairs

budownictwo / construction

zaopatrzenie w energię, gaz i wodę / electricity, gas and water supply

produkcja przemysłowa / manufacturing

górnictwo / mining and quarrying

rybołówstwo, hodowla ryb / fishing

rolnictwo, łowiectwo, leśnictwo / agriculture, hunting and forestry

Ryc. 6. Struktura zatrudnienia w badanych jednostkach regionu miejskiego Nowosybirska w $2012 \mathrm{r}$. The employment structure in the studied peripheral areas of the Novosibirsk urban region in 2012 


\section{Baza ekonomiczna regionu miejskiego Nowosybirska}

Zgodnie z przyjętymi założeniami kluczowym elementem postępowania badawczego w zakresie studiów nad strukturą ekonomiczną jest określenie bazy ekonomicznej Nowosybirska oraz wybranych jednostek administracyjnych (wzdłuż linii kolejowej Nowosybirsk-Czerepanowo). Baza ekonomiczna utożsamiana jest z funkcjami egzogenicznymi, które są podstawą powiązań z otoczeniem, a tym samym określają wielkość i charakter integracji danego ośrodka z systemem osadniczym państwa.

Zastosowana procedura obliczeń bazy ekonomicznej pozwoliła określić wielkość zatrudnienia egzogenicznego i w konsekwencji stopień otwarcia gospodarki miejskiej Nowosybirska i innych wziętych pod uwagę jednostek administracyjnych (ryc. 7). Poziom rozwoju funkcji egzogenicznych (baza ekonomiczna)

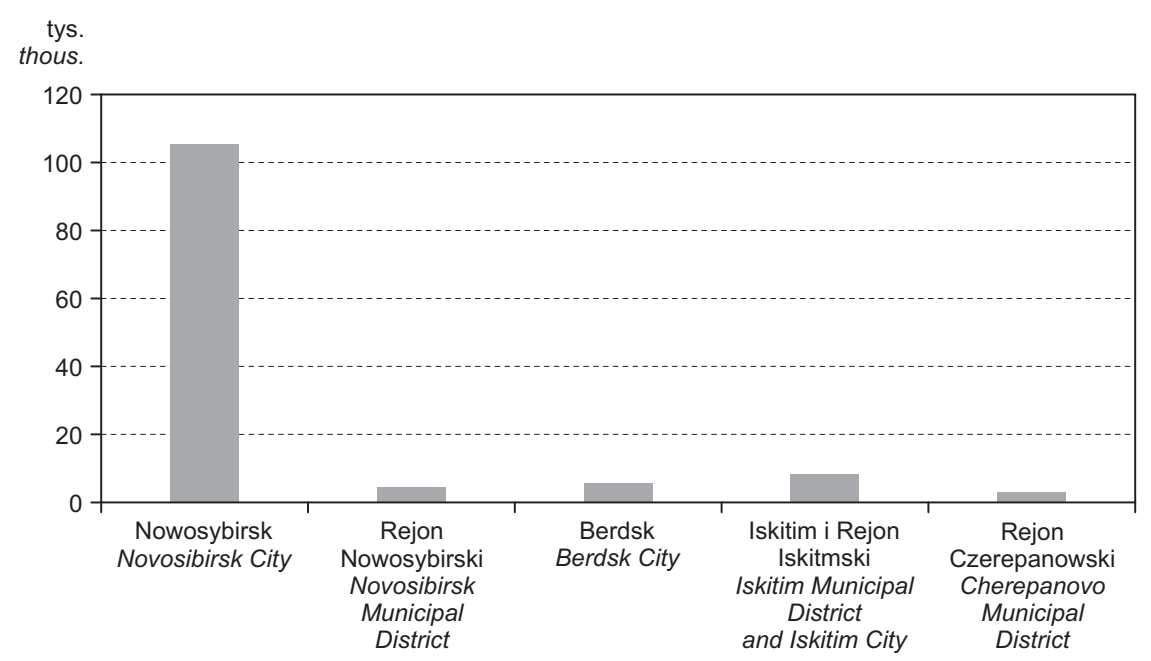

Ryc. 7. Wielkość bazy ekonomicznej badanych jednostkach regionu miejskiego Nowosybirska w $2012 \mathrm{r}$.

The size of the economic base in selected administrative units of the Novosibirsk urban region in 2012

Nowosybirska oszacowano na 105 tys. zatrudnionych (około 110 tys. łącznie z bliską strefą podmiejską). W porównaniu do stolicy regionu inne badane jednostki administracyjne (Berdsk, Rejon Iskitimski i Iskitim, Rejon Czerepanowski), podobnie jak w przypadku analizy struktury zatrudnienia w 2012 r., nie miały dużego znaczenia (łącznie ok. 17 tys. zatrudnionych).

Biorąc pod uwagę udział zatrudnienia egzogenicznego (bazy ekonomicznej) w ogólnym zatrudnieniu można określić wskaźnik otwarcia gospodarki określo- 
nego terytorium (ryc. 8). Zauważono, że niższe wartości wskaźnika są charakterystyczne dla rdzenia regionu miejskiego (Nowosybirsk i jego obszar podmiejski), tj. około 25\%. Związane jest to przede wszystkim z rozwojem ogromnego sektora endogenicznego obsługującego olbrzymie skupisko ludności w zakresie realizacji różnych potrzeb, zarówno w zakresie podstawowego i wyspecjalizowanego handlu, transportu, ale również przemysłu (np. spożywczego, tekstylnego), produkcji energii elektrycznej oraz usług edukacyjnych, kulturalnych oraz, co bardzo istotne dla kształtowania takich ośrodków, zyskującej na znaczeniu branży usług profesjonalnych (bankowość, ubezpieczenia, obsługa biznesu).

Obszary położone $\mathrm{w}$ strefie peryferyjnej mają wyższe wskaźniki otwarcia gospodarki (około 30-35\%). Związane jest to przede wszystkim z ich słabą dywersyfikacją ekonomiczną i stosunkowo niedużym ogólnym potencjałem - z przewagą dużych zakładów pracy, bądź o charakterze przemysłowym, bądź utrzymywanych przez państwo (administracja publiczna, obrona narodowa i ubezpieczenia społeczne, edukacja, ochrona zdrowia i opieka społeczna). Niewielki jest tu natomiast udział komercyjnych działalności usługowych. Obszary te znajdują się w polu obsługi Nowosybirska i skoncentrowanych tam wielu działalności wyspecjalizowanych (bardzo wysoka koncentracja przestrzenna).

Interesujący na tym tle jest istotny z punktu widzenia celów tej części pracy wynik pomiaru bazy ekonomicznej jednostek terytorialnych $\mathrm{w}$ odniesieniu do struktury funkcjonalnej (ryc. 9).

W rdzeniu regionu miejskiego (miasto Nowosybirsk) struktura funkcjonalna jest najbardziej zróżnicowana (8 funkcji egzogenicznych). Największe znaczenie $\mathrm{w}$ bazie ekonomicznej mają funkcje podporządkowane bezpośrednio działalności państwa, tj. administracja publiczna, obrona narodowa i ubezpieczenia społeczne (najważniejsza funkcja), edukacja oraz ochrona zdrowia i opieka społeczna. Razem tworzą one około 55\% bazy ekonomicznej miasta. Włączając do tej grupy działalność transportową, która również w dużym stopniu zależy od państwa, to udział ten wzrasta do 60\%. W kształtowaniu się funkcji wielkomiejskich (metropolitalnych) ważne są dwie grupy działalności ekonomicznych, związane z profesjonalnymi i komercyjnymi usługami, tj. obsługa nieruchomości i pośrednictwo finansowe (25\% bazy ekonomicznej). Funkcje, które miały w okresie komunistycznym kluczowe znaczenie dla kształtowania bazy ekonomicznej takich ośrodków, odgrywają dziś dużo mniejszą rolę w kształtowaniu systemu osadniczego Rosji. Aktywności produkcyjne stanowiły w 2012 r. około $15 \%$ bazy ekonomicznej.

W strefie zewnętrznej regionu miejskiego bazę ekonomiczną tworzy mniejsza liczba funkcji (7). W Berdsku, Rejonie Iskitimskim i w Iskitimiu zaznacza się równowaga pomiędzy branżami produkcyjnymi (ok. 40-50\%) oraz usługami ogólnospołecznymi. W przeciwieństwie do rdzenia regionu miejskiego tu w bazie ekonomicznej brak usług komercyjnych (Iskitim) lub mają one bardzo małe znaczenie (Berdsk). 


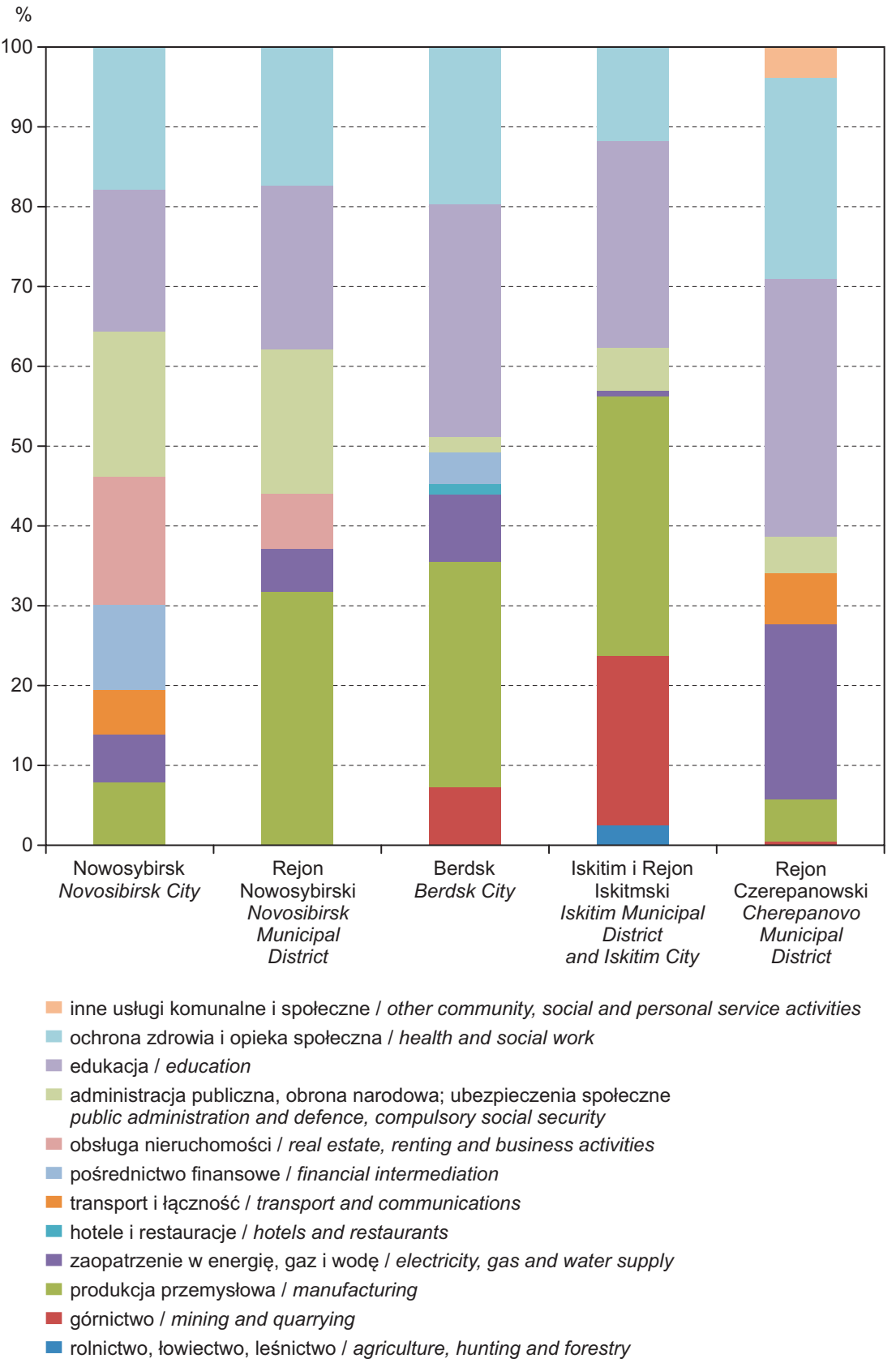

Ryc. 8. Poziom otwartości gospodarki badanych jednostek regionu miejskiego Nowosybirska w $2012 \mathrm{r}$.

Openness of the economies in selected administrative units of the Novosibirsk urban region in 2012 


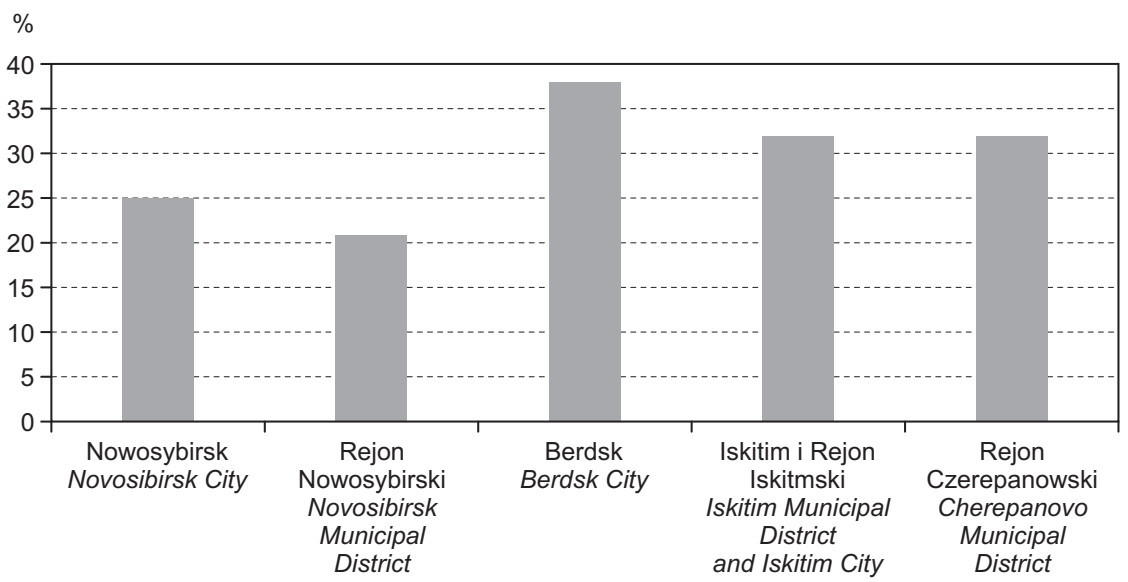

Ryc. 9. Baza ekonomiczna badanych jednostek regionu miejskiego Nowosybirska w 2012 r.

The size of the economic base of selected administrative of the Novosibirsk urban region in 2012

Na peryferiach regionu miejskiego (Czerepanowo), w strefie malejącego bezpośredniego odziaływania wielkiego miasta (Nowosybirsk) bazę ekonomiczną w przytłaczającej większości tworzy zatrudnienie w instytucjach państwowych, tj. szkołach różnego typu, szpitalach i ośrodkach ochrony zdrowia, urzędach i obsłudze transportu. Bazę ekonomiczną opartą na usługach publicznych uzupełnia przemysł.

\section{Wnioski końcowe}

Badania nad potencjałem demograficznym i ekonomicznym regionu miejskiego Nowosybirska z wykorzystaniem metody profilu kierunkowego pokazały ogólne tendencje w przekształceniach jego struktury przestrzennej - zarówno w długim czasie (ujęcie genetyczne rozwoju funkcji), jak we współczesnych warunkach, związanych z transformacją ekonomiczną Rosji.

Najważniejsze wnioski wynikające z przeprowadzonej analizy dotyczą następujących procesów kształtujących region miejski Nowosybirska.

1. Rozwój funkcji miastotwórczych Nowosybirska oraz związanych z nim osiedli (region miejski) był efektem decyzji o charakterze politycznym, tj. budowy kolei transsyberyjskiej (rosyjska kolonizacja Syberii i Dalekiego Wschodu) oraz lokalizacji przemysłu w strefie niezagrożonej bezpośrednimi działaniami wojennymi (II wojna światowa), a następnie tworzenia innych, wspomagających przemysł funkcji, zwłaszcza instytutów naukowych i szkolnictwa wyższego. 
2. Nowosybirsk i podległy mu bezpośrednio najbliższy obszar stał się najważniejszym regionem miejskim na Syberii, z silnie wykształconymi funkcjami przemysłowymi, wysoką koncentracją ludności i związanym z jej obsługą dobrze rozwiniętym sektorem usług publicznych (funkcje edukacyjne, naukowe, ochrony zdrowia, kulturalne i administracji).

3. Pierwszy okres postsowieckiej transformacji ekonomicznej (lata 1990.) spowodował kryzys demograficzny w Obwodzie Nowosybirskim, choć w większym stopniu dotknął on rdzeń regionu miejskiego Nowosybirska, przede wszystkim z uwagi na recesję w przemyśle przetwórczym. W strefie peryferyjnej, z uwagi na kryzys ekonomiczny w rdzeniu regionu miejskiego, liczba ludności była stosunkowo stabilna (osłabienie ruchów migracyjnych z peryferii do centrów uprzemysłowionych regionów).

4. W pierwszym dziesięcioleciu XXI w., gospodarkę Nowosybirska charakteryzował wzrost i przebudowa funkcjonalna, szczególnie jeśli chodzi o rozwój usług komercyjnych i publicznych. Przyczyniło się to do napływu ludności z obszarów peryferyjnych, zwłaszcza w wieku produkcyjnym mobilnym, co połączone było ze wzrostem przyrostu naturalnego. W konsekwencji wzrosła liczba ludności. W tym samym czasie $\mathrm{w}$ obszarach peryferyjnych regionu miejskiego, głównie ze względu na mniej atrakcyjny rynek pracy, nastąpiła depopulacja (głównie na skutek odpływu migracyjnego).

5. Baza ekonomiczna w regionie miejskim Nowosybirska wykazuje wysoką koncentrację funkcji egzogenicznych w rdzeniu, co przy ekstensywnym zagospodarowaniu większości obszaru Obwodu Nowosybirskiego i terenów otaczających, tworzy duże przestrzenne dysproporcje w poziomie rozwoju społeczno-ekonomicznego. Struktura sieci osadniczej została ukształtowana na bazie lokalizacji ośrodków wyspecjalizowanych, przede wszystkim w działalnościach przemysłowych (terytorialne kompleksy produkcyjne). Współczesna słabość funkcjonalna ośrodków lokalnych (brak pierwotnego układu hierarchicznego), zwłaszcza w zakresie rozwoju wielofunkcyjnego, przy recesji lub względnej stabilizacji funkcji przemysłowych, prowadzi do narastania tych dysproporcji w skali regionalnej, co w konsekwencji może doprowadzić do kryzysu bazy ekonomicznej mniejszych miast i osiedli.

6. Obecna struktura bazy ekonomicznej regionu miejskiego Nowosybirska jest efektem przebudowy funkcjonalnej przede wszystkim rdzenia (miasto Nowosybirsk). Najbardziej charakterystycznym przejawem tej transformacji jest zmniejszenie znaczenia egzogenicznych funkcji przemysłowych (choć nadal są istotne w strukturze zatrudnienia), przy wzroście znaczenia funkcji wielkomiejskich (metropolitalnych), tzn. wyspecjalizowanych usług oraz stabilizacji na wysokim poziomie działalności finansowanych przez państwo.

7. Wysoki udział funkcji administracji państwowej w bazie ekonomicznej, szczególnie rdzenia regionu miejskiego, jest wyrazem oddziaływania polityki centralistycznego zarządzania państwem. Interesujące jest małe znaczenie 
handlu w strukturze zatrudnienia i jego brak w strukturze bazy ekonomicznej, co nie tyle pokazuje małą jego rolę, ile może być świadectwem funkcjonowania działalności handlowych poza oficjalnym obiegiem.

8. Zidentyfikowana struktura bazy ekonomicznej jest mało korzystna dla kształtowania zrównoważonych funkcji miejskich i może być w przyszłości wrażliwa na różne odziaływania zewnętrzne. Baza ekonomiczna regionu miejskiego Nowosybirska zależy bowiem w dużej mierze od kondycji budżetu państwa, gdyż znaczna część działalności egzogenicznych finansowana jest przez władze centralne. Duży udział funkcji przemysłowych, w tym kopalnictwa, w strukturze zatrudnienia oraz $\mathrm{w}$ bazie ekonomicznej (zwłaszcza regionalnych peryferii) miast i osiedli może być przyczyną niekorzystnych tendencji rozwojowych w przypadku większych kryzysów, zwłaszcza na rynku surowców (spadek cen surowców). Mając na uwadze fakt, że dochód ze sprzedaży surowców (zwłaszcza energetycznych) jest jednym z najważniejszych wpływów do budżetu państwa, można przypuszczać, że jego spadek może w konsekwencji negatywnie oddziaływać na wydatki publiczne, w tym finansowanie zatrudnienia w usługach ogólnospołecznych.

\section{Piśmiennictwo / References}

Dawidowicz W.G., 1972, O ilościowych prawidtowościach urbanizacji w ZSRR, Przegląd Geograficzny, 44, 3, s. 437-451.

Dziewoński K. (red.), 1960, Zagadnienia regionalizacji ekonomicznej w Zwiazku Radzieckim, Przegląd Zagranicznej Literatury Geograficznej, 2.

Dziewoński K., 1971, Baza ekonomiczna i struktura funkcjonalna miast, Prace Geograficzne, IG PAN, 87.

Eberhardt P., 2002, Geografia ludności Rosji, Wydawnictwo Naukowe PWN, Warszawa.

Jerczyński M., 1973, Zagadnienia specjalizacji bazy ekonomicznej większych miast w Polsce. Studia nad struktura funkcjonalna miast, Prace Geograficzne, IG PAN, 97.

Jewtuchowicz A., Suliborski A., 2009, Ksztattowanie się funkcji gospodarczych Łodzi do 1918 roku, [w:] S. Liszewski (red.), Łódź. Monografia miasta, Łódzkie Towarzystwo Naukowe, Łódź, s. 125-168.

Jewtuchowicz A., Wójcik M. (red.) 2010, Łódzka Metropolia. Problemy integracji gospodarczej, Wydawnictwo Biblioteka, Łódź.

Korcelli P., 1981, Regiony miejskie w systemie osadniczym Polski, [w:] Studia nad migracjami i przemianami systemu osadniczego w Polsce, Prace Geograficzne, IGiPZ PAN, 140, s. 189-212.

Kukliński A., 1960, Przedmowa, [w:] J. Kostrowicki (red.), Zagadnienia geografii przemystu, Przegląd Zagranicznej Literatury Geograficznej, 3, s. 1-4.

Maryański A., 1995, Przemiany ludnościowe w ZSRR, Centrum Badań Wschodnich UW, WSP w Krakowie, Warszawa-Kraków.

Maryański A., Mróz G., Szot Z., Troc M., 1996, Geografia gospodarcza Rosji, PWE, Warszawa. Metody ilościowe w radzieckiej geografii ekonomicznej, 1970, Przegląd Zagranicznej Literatury Geograficznej, 3. 
Nevzgodin I., 2005, Architecture of Novosibirsk, Siberian Branch, Russian Academy of Sciences, Novosibirsk.

Pokszyszewski W.W., 1972, Urbanizacja i procesy etnograficzne, Przegląd Geograficzny, 44, 3, s. 453-462.

Procesy urbanizacji w ZSRR. Materiaty z I polsko-radzieckiego seminarium geograficznego, 1972, Przegląd Zagranicznej Literatury Geograficznej, 2.

Rykiel Z., 2002, Koncepcje i delimitacje wielkomiejskich form osadniczych w Polsce, [w:] I. Jażdżewska (red.), Wspótczesne formy osadnictwa miejskiego i ich przemiany. XV Konwersatorium Wiedzy o Mieście, Wydawnictwo Uniwersytetu Łódzkiego, Łódź, s. 9-19.

Seth A., 2007, Cold War frontier: Building the defense complex in Novosibirsk, [w:] J.A. Engel (red.), Local Consequences of the Global Cold War, Woodrow Wilson International Center of Scholars, Stanford, s. 140-168.

Suliborski A., 1983, Niektóre problemy badań funkcji miast w świetle podstawowych zatożen koncepcji systemowej, Acta Universitatis Lodziensis, Folia Geographica, 2, s. 3-16.

Suliborski A., 2001, Funkcje i struktura funkcjonalna miast. Studia empiryczno-teoretyczne, Wydawnictwo Uniwersytetu Łódzkiego, Łódź.

Suliborski A., 2010, Funkcjonalizm w polskiej geografii miast, Wydawnictwo Uniwersytetu Łódzkiego, Łódź.

Wites T., 2007, Wyludnianie Syberii i rosyjskiego Dalekiego Wschodu, Wydawnictwa Uniwersytetu Warszawskiego, Warszawa.

[Wpłynęło: sierpień 2015; poprawiono: luty 2016 r.]

\section{MARCIN WÓJCIK, PAULINA TOBIASZ-LIS}

\section{ECONOMIC FUNCTIONS OF THE URBAN REGION OF NOVOSIBIRSK. THE GENESIS AND CONTEMPORARY DEVELOPMENT TRENDS}

The research presented in this article focuses on the urban region of Novosibirsk, which is one of the most industrialised parts of the Russian Federation. To show relationships between the city as the core of the region and its peripheral area a case study was performed to analyse territorial units within the southern settlement belt along the Novosibirsk-Cherepanovo regional railway line over a distance of approx. $100 \mathrm{~km}$. This belt was chosen because of the continuity of settlement, and the presence of edge towns of different functional types. The adopted system, from the core to the area of weakening direct links with Novosibirsk, helped to define the directional profile of the urban region as related to its demographic and economic characteristics.

The research was based on two methods of determining the functions of cities within a national settlement system, i.e. research programmes on the genesis of functional development, and on specialised functions, the purpose of the latter being to determine the economic base (exogenous functions) of territorial units. The presented results show general trends where the transformation of spatial structure in the Novosibirsk urban region is concerned, in both the long-term perspective (the generic view of function development) and under contemporary circumstances relating to Russia's economic transformation. 
The main conclusions of the analysis relate to the following processes affecting the structures that shape the urban region of Novosibirsk.

1. The development of the city-forming functions of Novosibirsk and connected settlements was the result of political decisions involving the construction of the TransSiberian Railway, as well as a desire to locate industry in a zone not threatened directly by wartime activities (World War II), as followed by the generation of other functions in support of the industry, primarily scientific and higher education institutions.

2. Novosibirsk and the area in its immediate vicinity grew to become Siberia's largest urban region, with strong industrial functions, a high concentration of population and a well-developed public services sector serving it.

3. The first period of post-Soviet economic transition (the 1990s) gave rise to a demographic crisis in the Novosibirsk Region, though one more noticeable in the urban core than in the peripheral zone where the population remained relatively stable.

4. In the first decade of the twenty-first century, the economy of Novosibirsk experienced some growth and functional restructuring, especially as regards the development of commercial and public services. This contributed to an influx of population from the aforementioned peripheral areas, especially among mobile individuals of productive age, with the result that natural population growth in the core increased, while the peripheral areas experienced depopulation.

5. The economic base in the core of the Novosibirsk urban region has a very high concentration of exogenous functions, with the result that there are considerable spatial disparities in socio-economic development reflecting extensive development across most of the area.

6. The current structure of the economic base in the Novosibirsk urban region reflects a functional reconstruction that has focused on the core. This transformation is most characteristically evident in a declining significance of exogenous industrial functions, as accompanied by a growing importance of metropolitan functions, i.e. specialised services, as well as a stabilisation at a high level of state financial activity.

7. The large share of the economic base accounted for by government functions, especially in the core of the urban region, is an expression of the impact of a centralised state management policy. An interesting feature is the limited importance of commerce in the employment structure and the lack thereof in the structure of the economic base, with both features potentially reflecting the effect of commercial activity beyond official circulation.

8. The identified structure of the economic base is not very favourable to the development of balanced urban functions, and may in future be susceptible to various external influences. 